\title{
Fungal diversity, woody debris, and wood decomposition in managed and unmanaged Patagonian Nothofagus pumilio forests
}

\section{Ana Laura Gallo}

Centro de Investigación y Extensión Forestal Andino Patagónico

\section{Patricia Valeria Silva}

Centro de Investigación y Extensión Forestal Andino Patagónico

\section{Pablo López Bernal}

Universidad Nacional de la Patagonia San Juan Bosco

\section{Alicia Susana Moretto}

CADIC: Centro Austral de Investigaciones Cientificas

Alina G. Greslebin ( $\nabla$ agreslebin@gmail.com )

Centro de Investigación Esquel de Montaña y Estepa Patagónica https://orcid.org/0000-0001-85740152

\section{Research Article}

Keywords: ecosystem process, forest ecology, lenga, Patagonia, wood-inhabiting fungi.

Posted Date: April 6th, 2021

DOl: https://doi.org/10.21203/rs.3.rs-366022/v1

License: (c) (1) This work is licensed under a Creative Commons Attribution 4.0 International License. Read Full License 


\section{Abstract}

Fungal diversity, woody debris, and wood decomposition were assessed in Nothofagus pumilio forests with and without forest management. A plot in a managed forest (MF) and a plot in an unmanaged control forest (C) were established in three sites in Chubut, Argentina. On each plot, forest structure, volume of woody debris, temperature, and humidity were recorded. Basidiomata of aphyllophoroid fungi were recorded in the fall and spring for 2 years. A decomposition assay with branches and twigs in two decay classes (DC) was established, and mass loss was measured after 3 and 2 years of field incubation respectively. To evaluate fungal diversity and mass loss within MF and C, generalized linear mixed-effects models (GLMM) were performed. Neither richness nor abundance differed between treatments, and community composition was similar. Only branches in DC2 showed greater mass loss in MF than in C. The volume of CWD was greater in MF and had a positive effect on fungal richness. A few aphyllophoroid species showed significant differences in abundance between treatments. Forest management in the conditions evaluated did not generate evident changes in fungal diversity, nor in wood decomposition. However, the differences observed in mass loss of DC2 could indicate that there were some factors operating in the past, that are no longer seen in the present, which may have accelerated decomposition. This highlights the need for studies evaluating changes in canopy cover, microclimate and fungal community, including potential key species, over a period starting just after the forest management.

\section{Introduction}

Biodiversity influences the way in which ecosystems function (Loreau et al. 2001), but how ecosystem functioning and biodiversity are related is still poorly understood. Decomposition is a key process in ecosystem functioning because it causes the recycling of carbon and nutrients from dead organic matter (Swift 1977). Thus, understanding how biodiversity and decomposition are related is extremely important to forest conservation and sustainable management.

In forest ecosystems, the decomposition of wood is an essential and complex process regulated by different factors: environmental conditions, decomposer organisms, and wood traits. Their relative importance may change over time, during the different stages of this process (Weedon et al. 2009). For example, van der Wal et al. (2015) reported that moisture content is a relevant factor at the beginning of decomposition but then, as wood decomposition proceeds, the composition of the fungal community becomes more relevant. As regards wood traits, there is a general consensus that macronutrients, in particular nitrogen and phosphorus, are key factors in woody material decomposition (Weedon et al. 2009).

Wood-inhabiting fungi, especially aphyllophoroid fungi (Basidiomycota), are the main decomposer organisms in temperate forests (Rayner and Boddy 1988); hence, they play a key role in nutrient cycling and soil formation (Lonsdale et al. 2008) and, consequently, in forest maintenance. The diversity of wood decomposer fungi is affected by microclimate and the amount, types, and decay stage of the woody 
debris present in the forest (Parisi et al. 2018). As regards the characteristics of dead wood, previous works have reported that fungal diversity peaks in the most highly decayed substrates (Fischer et al. 2012; Rajala et al. 2012). Besides, a positive effect of increased stand structure heterogeneity on abundance and diversity of wood-inhabiting fungi has been reported by Persiani et al. (2016). The results of the effect of microclimate on fungal diversity are inconsistent: Some studies reported that woodinhabiting fungal diversity is negatively correlated with canopy openness and that fungal community composition changes in response to changes in canopy cover (Bässler et al. 2010; Horák et al. 2016), but other studies reported no effect of canopy openness on fungal diversity (Bässler et al. 2016). This relationship seems to be influenced by other factors too, for example Brazee et al. (2014) did not find an effect of canopy openness on fungal abundance and diversity alone, but when testing it in combination with coarse woody debris addition, they did find a positive effect. Anthropogenic disturbances, particularly intense forest management, may affect decomposer biodiversity because this practice changes the structure, tree cover, and plant community composition (Chen et al. 1999; Edmonds et al. 2000), modifies the amount, availability, and type of woody debris on the forest floor (Abrego and Salcedo 2013), and can affect microclimatic conditions (Aussenac 2000). In their meta-analysis based on 120 comparisons of species richness between unmanaged and managed forests throughout Europe, Paillet et al. (2010) reported that different ecological groups displayed contrasting responses to forest management. Particularly for fungi, they found that species richness was higher in unmanaged than in managed forests. Accordingly, other authors reported that fungal community diversity is influenced by management (Dvořák et al. 2017 and references therein). Thus, if forest changes caused by forest management may affect the fungal community, they might also affect the decomposition process.

The diversity and structure of the fungal community are known to affect decomposition (Hättenschwiler et al. 2011), but no clear relationships between decomposition rates and decomposer diversity in natural conditions have been demonstrated so far (Parisi et al. 2018). It is a standard view of ecology that increased microbial diversity will result in enhanced nutrient cycling because of functional niche complementarity (additive effect) or a greater intensity of resource exploitation (synergistic activities) (van der Wal et al. 2013). This view is supported by previous studies that showed a positive relationship between wood-inhabiting fungal richness and wood mass loss (Rajala et al. 2012; van der Wal et al. 2015). However, in vitro and field-based manipulative studies have shown that the diversitydecomposition relationship was saturated at rather low species levels (up to 10 species) (Setälä and McLean 2004; Dang et al. 2005; Gessner et al. 2010) and that the idiosyncratic relationship (where one species has a greater influence on ecosystem processes than others) is most frequently observed in communities with more than 10 species (Nielsen et al. 2011). In other words, intermediate levels of fungal diversity enhance decomposition in soil (Setälä and McLean 2004) and wood (Toljander et al. 2006), but higher levels of fungal diversity are associated with slow decomposition (Dang et al. 2005; Deacon et al. 2006; Toljander et al. 2006; Fukami et al. 2010; Gessner et al. 2010; Nielsen et al. 2011).

Nothofagus pumilio (lenga) forests, the main native forest resource in Patagonia, have historically been managed (Martínez Pastur et al. 2003; Bava and Rechene 2004). Previous studies in shelterwood systems in these forests have reported lower humidity and greater radiation and wind speed in managed 
forests than in unmanaged ones (Caldentey et al. 1999; Promis et al. 2010). Although litter and wood decomposition in these forests has been documented in several studies (Frangi et al. 1997; Decker and Boerner 2006; Ibarra et al. 2011; Mansilla 2012; Moretto and Martínez Pastur 2014; Gallo 2017; Gallo et

al. 2019) and wood-inhabiting fungi diversity has also been reported (Horak 1979; Greslebin 2002; Greslebin and Rajchenberg 2003; Rajchenberg 2006), no studies have assessed wood decomposition in relation to fungal diversity and forest management.

Given the importance of understanding the relation between mycobiota and wood decomposition, it is relevant to address information gaps in Patagonian Andes forests under management. Thus, our objective was to determine whether there were changes in the aphyllophoroid fungal community and in wood decomposition in managed $N$. pumilio forests, in comparison with the surrounding unmanaged forest. Specifically, we assessed whether fungal abundance and richness, as well as mass loss of branches and twigs, differed between managed and unmanaged forests. Moreover, we evaluated some key factors related to fungal community and wood decomposition, such as the amount of woody debris and their physicochemical traits and environmental variables, and analyzed its contribution to the fungal diversity and mass loss values observed in managed and unmanaged forest.

\section{Materials And Methods}

\subsection{Study area}

The study was conducted in pure N. pumilio stands in three sites in Chubut province, Argentina. The sites were located in a north-south gradient along $N$. pumilio distribution. Site 1 was the northernmost site (S $42^{\circ} 46^{\prime} \mathrm{W} 71^{\circ} 28^{\prime}$ ), Site 2 was at an intermediate gradient ( $43^{\circ} 49^{\prime} \mathrm{W} 71^{\circ} 28^{\prime}$ ), and Site 3 was southwards (S $44^{\circ} 50^{\prime} \mathrm{W} 71^{\circ} 43^{\prime}$ ). In each site, two stands corresponding to two treatments were selected: one in a managed forest (hereafter, MF) and the other in an unmanaged (unlogged) forest, i.e. control (hereafter, C). The MF stands had been managed 16-18 years before this study, with low to medium intensity (Online Resources, Table 1). Unmanaged neighbor stands (less than $1000 \mathrm{~m}$ apart from MF) were selected as control stands to represent the previous situation of managed forests. No previous management was recorded for these areas, but some individual tree extraction could have occurred. In each stand, a study plot of $1 / 4$ hectare was defined. A full characterization of each plot based on the measurement of different variables is shown in Online Resources, Table 2.

\subsection{Structural and climatic stand characterization}

On each plot, all trees (diameter $>10 \mathrm{~cm}$ ) were counted and the diameter at breast height (DBH) was measured. The basal area was determined as the sum of all cross-sections of the stems at $1.3 \mathrm{~m}$ height of the trees within the plot. Inside the plot, 15 circular subplots of $0.8 \mathrm{~m}$ radius were regularly established. Tree cover (measured as the percentage of canopy cover from a skyward-oriented photograph of canopy taken from the forest floor) and number and height of saplings (trees with diameter $<10 \mathrm{~cm}$ ) were measured in each subplot. 
In addition, temperature and relative humidity were recorded on each plot with a data logger (EL-USB-2 Lascar, UK) every $3 \mathrm{~h}$ during the study period to characterize the microclimatic conditions of the stands. Precipitation was inferred from the interpolated climate surfaces developed by Hijmans et al. (2005), with records from the 1950-2000 period. This surface has a 30 arc min spatial resolution of $\left(0.86 \mathrm{~km}^{2}\right)$.

The geographical location and altitude of each plot were recorded with a Garmin global positioning system unit and the aspect was evaluated in the center of the plot with a compass.

\subsection{Fungal sampling}

Fungal sampling was conducted in the fall and the spring of 2012 and 2013 (4 samplings). To avoid sampling bias due to climatic conditions that affect fruiting body production, the MF and $\mathrm{C}$ plots of each site were surveyed at the same time, and all sites were surveyed within 10-15 days. Ten circular subplots of $4 \mathrm{~m}$ radius were randomly established within each $1 / 4$ hectare plot in each sampling (total surface sampled in the 4 samplings $=2000 \mathrm{~m}^{2}$ ). In the subplots, all woody debris $>1 \mathrm{~cm}$ diameter and living trees were inspected for the presence of aphyllophoroid fungi (Corticiaceae and Polyporaceae s.l.). All basidiomata were recorded or collected when it was not possible to identify them in the field. Basidiomata growing on woody debris $<1 \mathrm{~cm}$ in diameter were sampled in a sub-subplot of $1.3 \mathrm{~m}$ radius located in the center of the $4 \mathrm{~m}$ radius subplot. The collected basidiomata were taken to the lab, air dried, and kept for further identification. To determine abundance, only the basidiomata recorded on different woody debris were considered different "individuals".

\subsection{Measurements of fungal diversity}

Alpha diversity was evaluated on each plot using abundance and richness of the 10 subplots; diversity was determined with the Shannon-Wiener $\left(H^{\prime}\right)$ index.

The variation in species composition among sites (beta diversity) was evaluated by analyzing the similarity between MF and C fungal communities, using the Bray-Curtis dissimilarity index (Bray and Curtis 1957):

$B C_{i j}=1-\left(\left(2 C_{i j}\right) /\left(S_{i}+S_{j}\right)\right)$

where $C_{i j}$ is the sum of the lesser values only for those species in common between both sites, and $S_{i}$ and $S_{j}$ are the total number of specimens counted at both sites. This index was chosen because it includes not only the presence but also the abundance of species.

\subsection{Measurements of number and volume of coarse and fine woody debris}

The number and the volume of coarse (CWD: $\geq 10 \mathrm{~cm}$ ) and fine (FWD: $>1 \mathrm{a}<10 \mathrm{~cm}$ in diameter) woody debris were measured. Measurements of CWD were performed in the entire plot $\left(2500 \mathrm{~m}^{2}\right)$, while those of FWD were performed in the same 15 subplots of $0.8 \mathrm{~m}$ radius used for saplings and canopy cover measurement. In both cases, the largest and smallest diameter and length of all woody debris found on the forest floor were measured. Height and diameter of all stumps were also measured, but only in MF plots because no stumps were found in C plots. Each woody debris was assigned to one of three decay 
stages: incipient, intermediate or advanced. Decay stage was assigned mainly according to wood hardness and shape, and presence of bark.

Woody debris volume was determined as Volume $=1 / 3 * \pi^{*} \mathrm{~h}\left(\mathrm{R}^{2}+\mathrm{r}^{2} * \mathrm{r}\right)$, where $h$ is height, $R$ is the largest radius, and $r$ is the smallest radius. Stump volume was determined as Volume $=\pi *(r)^{2} * h$.

\subsection{Decomposition assay}

To determine whether mass loss of branches and twigs differed between MF and $\mathrm{C}$ a decomposition assay with FWD in two diameter categories: $\mathrm{B}=$ branches $(>1 \mathrm{~cm}$ in diameter $)$ and $T=$ twigs $(<1 \mathrm{~cm}$ in diameter), and in two decay classes: 1 (incipient decay state) and 2 (intermediate decay state) was installed on each study plot. Decay classes (hereafter, DC) were defined according to the natural process observed in the forest. DC1 represented the beginning of the process and included woody debris with intact bark and sound wood with high resistance to knife penetration (up to $0.5 \mathrm{~cm}$ ). DC2 represented an intermediate decay stage and included decorticated woody debris, with altered wood and low resistance to knife penetration (>0.5 cm up to $1 \mathrm{~cm}$ ), but maintaining its shape. Within the commonly used 5-decayclass systems, DC1 corresponds to the first class and DC2 corresponds to the third class (Renvall 1995). DC1 and DC2 were chosen for this assay because more advanced decay classes are easily disaggregated leading to unreliable results because of material loss. The materials for the assay were obtained from the same stand where the assay was installed: FWD in DC1 was obtained from recently fallen crowns, and FWD in DC2 was collected from the forest floor. Hereafter, the four types of woody debris will be named as 1B (branches in DC1), 1T (twigs in DC1), 2B (branches in DC2), and 2T (twigs in DC2).

Branch portions of $25 \mathrm{~cm}$ in length were cut and processed as follows: 5 -cm portions (hereafter, subsamples) were taken for physicochemical analyses, and the remaining 20-cm portions (hereafter, samples) were used to determine mass loss in the field assay. Twigs from the same stand and the same DC were cut into 10-cm-long portions and mixed to obtain a composite sample. The composite sample of each stand and each DC was then divided into $10 \mathrm{~g}$ portions (samples); five of them were separated for chemical analyses and the rest were used to determine mass loss in the field assay.

The decomposition field assay was conducted using the in situ litterbag method. Litterbags were made of fiberglass mesh $(2 \mathrm{~mm})$. Branch litterbags contained 4 branches from the same DC and twig litterbags contained $10 \mathrm{~g}$ of the composite sample from the same DC.

To determine mass loss over time, in March 2012, 10 branch litterbags from each DC and 10 twig litterbags from each DC were placed on the forest floor of each study plot. Two branch litterbags and 2 twig litterbags ( 1 for each DC) were randomly placed on the forest floor in 10 subplots, regularly arranged within the plot. The material was harvested after 3 and 2 years for branches and twigs, respectively. The retrieved material was wrapped in plastic bags and transported from the forests to the laboratory, where it was cleaned and oven-dried at $60^{\circ} \mathrm{C}$ until constant weight. Mass loss was determined as a percentage of the original dry mass. Then, the mass loss of the 4 branches from each litterbag was averaged.

\subsection{Measurements of branch and twig chemical traits}


Branches were ground with a drill, and twigs were ground in a laboratory mill. Carbon content was determined by dry combustion at $430^{\circ} \mathrm{C}$. Nitrogen $(\mathrm{N})$ content was measured using the standard semimicro Kjeldahl procedure (Bremner and Mulvaney 1983) and phosphorus (P) content by spectrophotometry with ICP-OES Shimadzu simultaneous high resolution (model 9000). Cell wall components (hemicellulose, cellulose, lignin) and extractive contents were determined by successive extractions with neutral detergent (extractives) and acid detergent (hemicellulose), hydrolysis with $72 \%$ $\mathrm{H}_{2} \mathrm{SO}_{4}$ (cellulose) and ignition at $500^{\circ} \mathrm{C}$ (lignin) (van Soest 1963). Carbon, cell wall components, and extractive contents were assessed in 12 branch subsamples and 5 twig samples from each plot. Nitrogen content was assessed in 6 branch subsamples and 5 twig samples from each plot. Phosphorus was assessed in 3 branch subsamples and 3 twig samples from each plot.

\subsection{Density of woody debris}

Density of branches at the beginning of the decomposition assay was assessed in 12 subsamples in each DC from each plot and determined as $\delta=$ dry mass/saturated volume, according to Gayoso (2013).

\subsection{Data analyses}

Fungal richness, abundance, and Shannon diversity index were analyzed using generalized linear mixedeffects models (GLMM) (Zuur et al. 2009). Collinearity was checked between predictors, and variables with magnitudes greater than the pre-selected threshold were removed $(r= \pm 0.5)$. The models included the predictor management (two classes: MF and C) and the following covariates: canopy cover, mean temperature, mean humidity, CWD volume, and FWD volume as fixed effects; the random effect of the factor site (with three levels, Site 1,2, and 3) was included as a random intercept to model between site variations. An automatic backward stepwise approach was applied for model selection using the command "drop1", and the best-fitting model did not include any of the covariates. However, because the model that included CWD volume as covariate showed that this variable seems to be associated with fungal variables, generalized linear models (GLM) that included CWD volume as a fixed effect were also performed for fungal richness, abundance, and diversity to explore this possible association. The fungal richness response variable was modeled assuming a Poisson distribution of errors and log link function, while fungal abundance was modeled with a Gamma family distribution and log link function. A Gaussian family distribution and log link function were used for Shannon diversity. Residual plots were examined for model validation following the protocol described by Zuur et al. (2009): i) residuals versus fitted values, ii) residuals versus each explanatory variable included and not included in the model, using the packages lattice (Sarkar 2008) and ggplot2 (Wickham 2016).

To analyze beta diversity, the dissimilarity matrix (constructed with the Bray-Curtis index) was submitted to cluster analysis, with clusters built using the Ward linkage method because it minimizes the total error sum of squares in the dendrogram (Legendre and Legendre 1998).

Woody debris mass loss was also analyzed using GLMM. Collinearity was checked between predictors, and environmental, fungal, and woody debris variables with magnitudes greater than the pre-selected threshold were removed $(r= \pm 0.5)$. Different models that included the predictor treatment (two classes: 
MF and C), the type of woody debris (four classes: 1B, 1T, 2B, 2T), their interaction, and the covariates mean humidity, mean temperature, canopy cover, fungal abundance, and percentage of hemicellulose were tested as fixed effects. To take into account the spatial structure of the data, the random effect of subplots nested within the factor site was included. Random intercepts that model between-site and between-subplot variation within the site were employed. The command "drop1" was used for model selection, and the best-fitting model did not include any of the covariates. The response variable was modeled assuming a Gamma distribution of errors and log link function. Residual plots were examined as described above.

Although the contribution of the structural and microclimatic variables, as well as of the woody debris physicochemical traits, to the different models was checked and discarded, t-tests were also performed to analyze whether there were differences in structural and microclimatic variables and in woody debris physicochemical traits between managed and unmanaged forests. In addition, to assess the variation ranges of mean values and standard errors, descriptive summary measures of the structure and environmental characteristics of each treatment were obtained.

Modeling was performed in R software, Version 3.6.2 (R Core Team 2016) via the RStudio software, Version 1.2.5033 (RStudio Team 2016), using "glm" and "glmer" functions from Ime4 package. The function "drop1" from the same package was used for model selection, and the function "Ismeans" from Ismeans package was used to perform the contrasts. Cluster analysis was conducted in InfoStat software (Di Rienzo et al. 2013). To create the artworks, Infostat software and Corel DRAW X7 were used.

\section{Results}

\subsection{Mycobiota}

A total of 2777 specimens of aphyllophoroid fungi corresponding to 50 species were recorded in MF plots, and a total of 2291 specimens of aphyllophoroid fungi corresponding to 44 species were recorded in C plots. The mean richness was $35.67( \pm 2.89)$ in MF and $30.67( \pm 6.43)$ in C, the mean abundance was $925( \pm 71.6)$ in MF and $763( \pm 69.87)$ in $C$, and the mean diversity $\left(H^{\prime}\right)$ was $2.09( \pm 0.21)$ in MF and $1.94( \pm$ 0.18 ) in $\mathrm{C}$. According to the best-fitting models, which only included treatment as a fixed effect, fungal richness, abundance, and diversity were similar in both treatments ( $p$ value $=0.305,0.111$ and 0.869 respectively). The volume of CWD had a significantly positive effect on fungal richness, but not on fungal abundance or diversity index (Table 1 ). 
Table 1

Generalized linear models (GLM) for the effect of volume of CWD on fungal richness, abundance, and diversity.

\begin{tabular}{|lllll|}
\hline Model & Explanatory variables & $\boldsymbol{\beta} \pm$ SE & z value & p value \\
\hline Fungal_richness & Intercept & $1.517 \pm 0.085$ & 17.751 & $<2 \mathrm{e}-16$ \\
& CWD_volume & $0.001 \pm 0.0002$ & 2.908 & $\mathbf{0 . 0 0 3 6}$ \\
& & & t value & \\
Fungal_abundance & Intercept & $18.642 \pm 5.508$ & 3.385 & 0.0009 \\
& CWD_volume & $0.0245 \pm 0.016$ & 1.512 & 0.1321 \\
\hline Fungal_diversity & Intercept & $1.100 \pm 0.134$ & 8.236 & $2.82 \mathrm{e}-14$ \\
& CWD_volume & $0.0001 \pm 0.0004$ & 0.255 & 0.7990 \\
\hline
\end{tabular}

Explanatory variables, parameter estimates $(\beta)$ ( \pm Standard Error $), \mathrm{z}, \mathrm{t}$ and $p$-Values are shown.

The assemblage of the species was also similar between treatments. Cluster analysis using the BrayCurtis dissimilarity index showed that MF and $\mathrm{C}$ stands of each site were more similar between them than between stands of the same treatment and different sites. The communities of each site grouped together, indicating that geographical location has a greater influence than treatments on fungal diversity (Fig. 1). Site 1 showed the maximum dissimilarity between treatments and it was low (0.20), while sites 2 and 3 showed very low dissimilarity ( 0.14 and 0.11 , respectively).

Figure 1 Hierarchical dendrogram of the cluster analysis showing dissimilarity between fungal assemblages of the 6 stands

The dendrogram is based on Bray-Curtis dissimilarity index. A Bray-Curtis index $=0$ indicates identical species assemblage, while index $=1$ indicates totally different species assemblage. Ward distance linkage was used. MF and C indicate managed forest and control, respectively. Each stand is labeled with the treatment and site number.

\subsection{Woody debris, structural, and microclimatic variables}

Coarse woody debris volume was significantly greater in MF than in C, but no differences were found in fine woody debris volume. Structural and climatic variables, as well as sapling density and average height of the highest sapling, showed similar mean values in MF and C, except for the basal area, which was significantly greater in C than in MF (Table 2). 
Table 2

Structural and microclimatic variables, and woody debris volume from different treatments (MF = managed forest, $\mathrm{C}=$ control).

\begin{tabular}{|c|c|c|c|c|}
\hline Variable & MF & C & $\begin{array}{l}t \\
\text { value }\end{array}$ & $\begin{array}{l}p \\
\text { value }\end{array}$ \\
\hline Mean temperature $\left({ }^{\circ} \mathrm{C}\right)$ & $5.7(0.28)$ & $5.5(0.10)$ & 0,96 & 0,4380 \\
\hline Maximum temperature $\left({ }^{\circ} \mathrm{C}\right)$ & $29.3(0.93)$ & $27.3(0.73)$ & 1,31 & 0,3206 \\
\hline Minimum temperature $\left({ }^{\circ} \mathrm{C}\right)$ & $-13.5(1.40)$ & $-12.8(1.86)$ & $-0,92$ & 0,4557 \\
\hline Mean humidity (\%) & $72.8(1.53)$ & $73.0(2.77)$ & $-0,12$ & 0,9162 \\
\hline Minimum humidity (\%) & $12.0(1.44)$ & $12.5(1.04)$ & $-0,33$ & 0,7745 \\
\hline Canopy cover (\%) & $55.3(6.01)$ & $69.3(0.67)$ & $-2,59$ & 0,1225 \\
\hline Basal area $\left(\mathrm{m}^{2} \mathrm{ha}^{-1}\right)$ & $25.5(4.8)$ & $55.9(9.67)$ & $-5,99$ & 0,0268 \\
\hline $\begin{array}{l}\text { Average height of the highest sapling } \\
(\mathrm{cm})\end{array}$ & $133.2(45.52)$ & $30.67(13.86)$ & 2.65 & 0.1181 \\
\hline Sapling density (saplings $\mathrm{ha}^{-1}$ ) & $\begin{array}{l}35166.67 \\
(17253.82)\end{array}$ & $\begin{array}{l}44000.00 \\
(19495.73)\end{array}$ & -1.22 & 0.3472 \\
\hline CWD volume $\left(\mathrm{m}^{3} \mathrm{ha}^{-1}\right)$ & $418.3(69.8)$ & $239.8(61.9)$ & 5,33 & 0,0335 \\
\hline FWD volume $\left(\mathrm{m}^{3} \mathrm{ha}^{-1}\right)$ & $27.8(6.6)$ & $21.03(5.0)$ & $-0,54$ & 0,6445 \\
\hline
\end{tabular}

Structural and environmental variables showed more dissimilar values between sites than between treatments (Online Resource, Table 2).

\subsection{Decomposition assay}

The best-fitting model included the treatment, the type of woody debris, and their interaction. This model showed that there was a significant effect of the interaction between treatment and type of woody debris on mass loss ( $p$ value $=0.0145)$. According to this model, significantly greater values of mass loss for branches in DC2 were found in MF in comparison with C (Fig. 2; Table 3). In the other type of woody debris, no significant differences were found between MF and C (Table 3).

Figure 2 Mass loss of branches and twigs in different decay classes

A: branches; B: twigs; DC1: incipient decay class DC2: intermediate decay class; MF: managed forests; C: control. Mass loss is presented as a percentage of initial mass. Mean values ( \pm Standard Error) 
Table 3

Contrasts for generalized linear mixed model for the effect of treatment, type of woody debris and their interaction.

\begin{tabular}{|lllll|}
\hline Contrast & MF & C & $\boldsymbol{\beta} \pm$ SE & $p$-Value \\
\hline MF_1B - C_1B & $35.0 \pm 1.9$ & $32.2 \pm 3.3$ & $0.008 \pm 0.004$ & 0.5687 \\
MF_1T - C_1T & $25.8 \pm 2.1$ & $20.9 \pm 0.9$ & $0.013 \pm 0.005$ & 0.1695 \\
\hline MF_2B - C_2B & $36.3 \pm 2.4$ & $23.4 \pm 2.7$ & $0.019 \pm 0.005$ & 0.0012 \\
\hline MF_2T - C_2T & $24.4 \pm 2.3$ & $23.5 \pm 3.3$ & $0.006 \pm 0.005$ & 0.9193 \\
\hline
\end{tabular}

Mean mass loss in each treatment $(\mathrm{MF}=$ managed forest, $\mathrm{C}=$ control $)$ for each type of woody debris $(\mathrm{B}=$ branch, T = twig; 1 = DC1, 2 = DC2) and standard error (in brackets), parameter estimates ( $\beta$ ) and Standard Error (in bracket), and p-Value are shown.

Density of branches at the beginning of the decomposition assay did not significantly differ between treatments ( $t=-0.08, p=0.943$ and $t=1.8, p=0.214$ for $D C 1$ and $D C 2$ respectively), but branches in DC2 tended to be less dense in MF than in $\mathrm{C}$, while branches in DC1 were almost equally dense in both treatments (Online Resources, Fig. 1). Components and nutrients of branches and twigs from MF and $\mathrm{C}$ showed similar values (Online Resources, Table 3).

\section{Discussion}

Based on previous works that reported that wood-inhabiting fungi are very sensitive to forest structure and, thus, that forest management alters the fungal community (Juutilainen et al. 2014; Persiani et al. 2016), we expected differences in fungal diversity, and possibly also in woody debris mass loss, between Nothofagus pumilio forests that had been subjected to forestry and those that had not. Contrary to our expectations, we found no significant differences in aphyllophoroid abundance or diversity, and none of the structural and/or microclimatic variables of the forest significantly contributed to the modeling of fungal diversity in relation to forest management. The only observed association was that aphyllophoroid fungal richness was favored by the volume of CWD.

It is understandable that the structural and microclimatic variables in this study did not contribute to the modeling of the response variables because they did not show significant differences between MF and C, except for the basal area that, as could be expected, was significantly greater in unmanaged forests. The variables that we initially predicted to be associated with changes in fungal diversity (i.e. canopy cover and average humidity) showed similar mean values in MF and C. This result might indicate that $\cong 20$ years after the intervention, the crown expansion of the remaining trees was able to fill the gaps, at least partially, and, together with the growth of saplings, generated similar conditions of vegetation cover at forest floor level. Thus, microclimatic variables, which are highly affected by the tree cover, were similar in MF and $\mathrm{C}$. 
Surprisingly, mass loss showed significant differences between MF and C, although in only one of the woody debris types evaluated: branches in the intermediate decay stages. Branches and twigs with sound wood and intact bark, as well as twigs in the intermediate decay stages, showed similar mass losses. The lack of significant differences in decomposition is a reasonable result. The key factors of this process (fungal diversity and environmental variables), which were expected to be affected by forest management, showed no significant differences between treatments. The other key factor that regulates wood decomposition, wood chemical traits, did not contribute to mass loss modeling and showed similar mean values between treatments (Online Resources, Table 3).

The question that remains is: Why was mass loss of branches in DC2 greater in MF than in C? Could it have been due to the interaction of forest management with some physical characteristic of this DC? If so, why mass loss of twigs in DC2 was not greater in MF than in C? We did not find any substantial differences in physicochemical traits of woody debris between MF and C. However, even not significant, at the beginning of the decomposition assay, the wood density of woody debris in DC2 in MF stands was lower than in $\mathrm{C}$ stands (Online Resources, Fig. 1). This could lead to the formulation of another hypothesis to explain why we only observed differences in branches in DC2: it may have been the result of factors occurring in the past and no longer taking place at present. Branches in DC2 have been on the forest floor for many years, as opposed to branches in DC1 which belonged to recently fallen trees; hence, the slightly lower density of branches in DC2 in MF forest could be related to factors that accelerated decomposition or produced faster degradation of some component in the first years after intervention but are no longer operating. The reason why mass loss of twigs in DC2 did not differ between treatments could be that, because of their very small diameter, the twigs reaching the forest floor at the same time as branches in DC2 should have been almost totally decomposed by the beginning of the study (Gallo et al. 2019); thus, the twigs in DC2 used in the experiment must have reached the forest floor later than the branches in DC2.

Alternatively, could it have been due to the interaction of forest management with some key group of decomposer organisms? Previous works have shown that the type of interactions between fungal species determines the relationship between fungal diversity and decomposition rate (van der Wal et al. 2013) and that changes in community composition, rather than richness, are more important for carbon dynamics (Nielsen et al. 2011). In our study, we did not find substantial changes in community composition, and the most abundant species were almost the same in MF and C (Online Resources, Table 4). However, woody debris in the intermediate decay stage were the substrate of most of the recorded basidiomata (51\% in MF and 48\% in C) (Online Resources, Table 5), suggesting that it would be the most suitable decay stage for aphyllophoroid species. Could small changes in species abundance associated with this decay stage have led to the observed mass loss changes? As mentioned by Nielsen et al. (2011), some species have a greater influence than others on ecosystem processes. Friedman non parametric analysis of variance (Online Resource, Table 6) showed significant differences between MF and $\mathrm{C}$ in the abundance of basidiomata of only four species: Amyloathelia aspera that was more abundant in $\mathrm{C}$ than in MF, and Botryobasidium spp., Phanerochaete velutina and Sistotrema brinkmanii that were more abundant in MF than in C. Among these species, Phanerochaete velutina is the most 
important wood decomposer. This white-rot fungi has a high efficiency to produce extracellular enzymes capable of completely degrading lignocellulose (Lee et al. 2014), and it was most frequently recorded (almost $60 \%$ of basidiomata) on woody debris in the intermediate decay stage (Online Resources, Table 7). It should be noted that we assessed aphyllophoroid fungal diversity through the presence of basidiomata, which need specific conditions to develop. This implies an underestimation of this variable. Anyway, as fungal sampling was done at the same time in all sites, the variability in fruiting body formation due to climatic conditions was minimized; hence, the data from MF and C plots are comparable.

Effects of management on biodiversity has been widely studied for different taxa (plants, bryophytes, insects and birds) in N. pumilio forests of Tierra del Fuego (Deferrari et al. 2001; Spagarino et al. 2001; Lencinas et al. 2008, 2009, 2011, 2014; Peri et al. 2016) and for plants in Chubut (Silva et al. 2016). Results of these works show that the effects of forest management on biodiversity differ according to the management system, time elapsed since intervention, and the taxonomic group considered. The greatest effects are usually observed in the first years after cutting and these effects diminish substantially when the forest canopy closes during the initial growth phase, returning to values similar to the one of the unlogged forest when the mature phase is reached (Deferrari et al. 2001; Martínez Pastur et al. 2002; Pérez Flores et al. 2019). Our sites of study were in the initial growth phase and, possibly, the relatively low harvest intensity contributed to the rapid recovery of tree cover. Regarding the taxonomic group considered in our study, fungal richness showed to be positively affected by the amount of CWD, which agrees with findings for other forests (Blaser et al. 2013; Seibold et al. 2015). Logging of N. pumilio stands usually left a great amount of logging residues because rotten logs and crowns are left on the forest floor. Accordingly, the volume of CWD was greater in MF than in C, which would suggest a positive effect of the forest intervention during the initial growth phase. This highlights the need to perform studies about the effect of forest management on fungi during the different phases after logging.

On the other hand, Lencinas et al. 2017 showed that harvesting impacts on plants and beetles were not uniform in N. pumilio forests along a regional gradient in Tierra del Fuego, and that the differences seem to be related with the composition of original assemblages of species of each site and the influx of species from surrounding environments. Thus, the wide geographical range of our study sites, even contributed to $N$. pumilio forest representativeness, could have diminished the possibility of detecting differences between treatments due to the variations along the geographical gradient.

Finally, regarding forest management in a landscape context, traditional forest use in Chubut province consisted in the selective cut of the better timber trees, which generally did not exceed $10 \%$ of forest trees (López Bernal et al. 2012). Application of forest management systems, which ranged from a group selection system up to a variation of shelterwood-cut systems, started in Chubut province after ' 80 decade of the past century (López Bernal et al. 2012); but, as in other forests of Patagonia, these theoretical methods were not fully applied and only the first cuts were implemented, without the final shelterwood removal and any intermediate treatments (Gea-Izquierdo et al. 2004). Moreover, as harvestings have been focused in the most accessible and highest site quality forests (Gea-Izquierdo et 
al. 2004), they were usually applied to small and scattered areas, resulting in discontinued managed patches in a matrix of no or slightly logged forests. This was the case of the MF areas of this study, which had been subject of the first cut of a shelterwood-cut system with low harvest intensity (39-61\% of extracted basal area, Online Resources, Table 1), applied to a total area of $<10$ ha, and where the surroundings forest remained unlogged or with scattered extraction of selected individuals. This situation contributes to morigerate effects of harvest on fungal diversity since, in case that some species were negatively affected by harvest, the surroundings unlogged forest constituted a source of inoculum from which the original biodiversity of logged areas could have been restored through recolonization.

\section{Conclusions}

This study conjointly analyzes for the first time the diversity of wood inhabiting fungi and the wood decomposition in managed vs. unmanaged forests. It is also the first study on fungal diversity in relation with wood decomposition in South American temperate forests. It describes wood decomposition and their main control variables in stands in managed forests vs. stands without known forest use. Our aim was to find a pattern that could be associated with forestry interventions. We found significant differences in mass loss of one of the four types of woody debris studied but we did not find significant differences in any of the assumed key variables. The scope of this study does not allow us to explain the difference in decomposition between MF and C, but we can hypothesize that it could be related to effects of forest management that occurred in the past but are no longer occurring at present. Further experiments are needed to disentangle the complex interactions between environmental and woody debris characteristics driving the differences in mass loss in DC2. These studies should focus on forests that were managed at different times in the past so that the changes in decomposition and its control factors can be analyzed after disturbance. Such studies should analyze variation over time in canopy cover, microclimate and fungal community, including potential key species as Phanerochaete velutina.

\section{Declarations}

Funding: This work was supported by Agencia Nacional de Promoción Científica y Técnica (ANPCyT, FONCYT, PICT 2010-1229).

Conflicts of interest/Competing interests: the authors declare that they have no competing interests.

Availability of data and material: most of the data generated and/or analyzed during this study are included in this published article and in its additional information files. If the datasets needed are not there, they are available from the corresponding author on reasonable request.

Code availability: not applicable

Authors' contributions: all authors contributed to the study conception and design. Material preparation and data collection were performed by Patricia Valeria Silva, Ana Laura Gallo, Alicia Susana Moretto, and Alina Gabriela Greslebin. Formal analyses were performed by Ana Laura Gallo, Pablo López Bernal, and 
Alina Gabriela Greslebin. The first draft of the manuscript was written by Ana Laura Gallo and Alina Gabriela Greslebin, and all authors commented on previous versions of the manuscript. All authors read and approved the final manuscript.

Ethics approval and consent to participate: not applicable

Consent for publication: not applicable

Acknowledgments: We are grateful to Dr. Érica Ruiz (UNPSJB), Mr. Juan Monges (CIEFAP) and Mr. Momberg and Mr. Soto (DGByP) for their help with field work, and to Dr. Marta Grech for her help with statistical analyzes.

\section{References}

Abrego N, Salcedo I (2013) Variety of woody debris as the factor influencing wood-inhabiting fungal richness and assemblages: is it a question of quantity or quality? For. Ecol. Manage. 291: 377-385. doi: 10.1016/j.foreco.2012.11.025

Aussenac G (2000) Interactions between forest stands and microclimate: ecophysiological aspects and consequences for silviculture. Ann. For. Sci. 57(3): 287-301. doi: 10.1051/forest:2000119

Bässler C, Müller J, Cadotte MW, Heibl C, Bradtka JH, et al. (2016) Functional response of lignicolous fungal guilds to bark beetle deforestation. Ecological Indicators. 65: 149-160. doi:

10.1016/j.ecolind.2015.07.008

Bässler C, Müller J, Dziock F, Brandl R (2010) Effects of resource availability and climate on the diversity of wood-decaying fungi. J. Ecol. 98(4): 822-832. doi: 10.1111/j.1365-2745.2010.01669

Bava J, Rechenne D (2004) Dinámica de la regeneración de lenga (Nothofagus pumilio (Poepp. et Endl) Krasser) como base para la aplicación de sistemas silvícolas. In: Arturi MF, Frangi JL, Goya JF (eds.) Ecología y manejo de los bosques de Argentina. Universidad Nacional de La Plata, Argentina, pp. 1-22

Blaser S, Prati D, Senn-Irlet B, Fischer M (2013) Effects of forest management on the diversity of deadwood-inhabiting fungi in Central European forests. For. Ecol. Manage. 304: 42-48. doi: 10.1016/j.foreco.2013.04.043

Bray JR, Curtis JT (1957) An ordination of upland forest communities of southern Wisconsin. Ecol. Monogr. 27: 325-349. doi: 10.2307/1942268

Brazee NJ, Lindner DL, D’Amato AW, Fraver S, Forrester JA, Mladenoff DJ (2014) Disturbance and diversity of wood-inhabiting fungi: effects of canopy gaps and downed woody debris. Biodiversity and Conservation. 23: 2155-2172. doi: 10.1007/s10531-014-0710-x 
Bremner JM, Mulvaney CS (1983) Nitrogen-total. Methods of soil analysis: Part 2 chemical and microbiological properties. 9: 595-624.

Caldentey J, Promis A, Schmidt H, Ibarra M (1999) Variación microclimática causada por una corta de protección en un bosque de lenga (Nothofagus pumilio). Ciencias Forestales. 14(1-2): 51-59.

Chen J, Saunders SC, Crow TR, Naiman RJ, Brosofske KD, et al. (1999) Microclimate in forest ecosystem and landscape ecology: variations in local climate can be used to monitor and compare the effects of different management regimes. BioScience 49(4): 288-297. doi: 10.2307/1313612

Dang CK, Chauvet E, Gessner MO (2005) Magnitude and variability of process rates in fungal diversitylitter decomposition relationships. Ecology letters 8(11): 1129-1137. doi: 10.1111/j.1461-

0248.2005.00815.x

Deacon LJ, Pryce-Miller EJ, Frankland JC, Bainbridge BW, Moore PD, Robinson CH (2006) Diversity and function of decomposer fungi from a grassland soil. Soil Biol. Biochem. 38(1): 7-20. doi:

10.1016/j.soilbio.2005.04.013

Decker KL, Boerner RE (2006) Mass loss and nutrient release from decomposing evergreen and deciduous Nothofagus litters from the Chilean Andes. Austral Ecology 31(8): 1005-1015. doi: 10.1111/j.1442-9993.2006.01670.x

Deferrari G, Camilión C, Martínez Pastur G, Peri PL (2001). Changes in Nothofagus pumilio forest biodiversity during the forest management cycle. 2. Birds. Biodiversity \& Conservation. 10(12): 20932108. doi: 10.1023/A:1013154824917

Di Rienzo JA, Casanoves F, Balzarini MG, Gonzalez L, Tablada M, Robledo CW (2013) InfoStat. Córdoba, Argentina. Universidad Nacional de Córdoba.

Dvořák D, Vašutová M, Hofmeister J, Beran M, Hošek J, et al. (2017) Macrofungal diversity patterns in central European forests affirm the key importance of old-growth forests. Fungal Ecology 27: 145-154. doi: 10.1016/j.funeco.2016.12.003

Edmonds RL, Marra JL, Barg AK, Sparks GB (2000) Influence of forest harvesting on soil organisms and decomposition in western Washington. Proceedings of the California Forest Soils Council Conference on Forest Soils Biology and Forest Management. Gen. Tech. Rep. U.S Department of Agriculture. pp. 53-72

Fischer AL, Moncalvo JM, Klironomos JN, Malcolm JR (2012) Fruiting body and molecular rDNA sampling on fungi in woody debris from logged and unlogged boreal forests in northeastern Ontario. Ecoscience 19(4): 374-390. doi: 10.2980/19-4-3513

Frangi JL, Richter LL, Barrera MD, Aloggia M (1997) Decomposition of Nothofagus fallen woody debris in forests of Tierra del Fuego, Argentina. Can. J. For. Res. 27(7): 1095-1102. doi: 10.1139/x97-060 
Freschet GT, Weedon JT, Aerts R, van Hal JR, Cornelissen JH (2012). Interspecific differences in wood decay rates: insights from a new short-term method to study long-term wood decomposition. J. Ecol. 100(1): 161-170. doi: 10.1111/j.1365-2745.2011.01896.x

Fukami T, Dickie IA, Wilkie JP, Paulus BC, Park D, et al. (2010) Assembly history dictates ecosystem functioning: evidence from wood decomposer communities. Ecology Letters 13(6): 675-684. doi: 10.1111/j.1461-0248.2010.01465.x

Gallo AL (2017) Efecto del uso forestal sobre el proceso de degradación de la madera y el ciclo de nutrientes en los bosques de Nothofagus pumilio. Universidad Nacional de Córdoba. Córdoba, Argentina. $193 \mathrm{p}$.

Gallo AL, Moretto AS, López Bernal P, Greslebin AG (2019) Characterization and decomposition of Nothofagus pumilio fine woody material. Can. J. For. Res. 49(6): 715-720. doi: 10.1139/cjfr-2018-0185

Gayoso J (2013) Funciones alométricas para la determinación de existencias de carbono forestal para la especie Nothofagus pumilio (Poepp. et Endl.) Krasser (lenga). CONAF. Santiago de Chile, Chile. pp. 1-40.

Gea-Izquierdo G, Martínez Pastur G, Cellini JM, Lencinas MV (2004) Forty years of silvicultural management in southern Nothofagus pumilio primary forests. For. Ecol. Manage. 201(2-3): 335-347. doi: 10.1016/j.foreco.2004.07.015

Gessner MO, Swan CM, Dang CK, McKie BG, Bardgett RD, et al. (2010) Diversity meets decomposition. Trends in Ecology and Evolution 25(6): 372-380. doi: 10.1016/j.tree.2010.01.010

Greslebin AG (2002) Flora criptogámica de Tierra del Fuego. Fungi, Basidiomycota, Aphyllophorales: Coniophoraceae, Corticiaceae, Gomphaceae, Hymenochaetaceae, Lachnocladiaceae, Stereaceae, Thelephoraceae. Tulasnellales: Tulasnellaceae. Buenos Aires, Argentina. Tomo XI, Fasc. 4. Fundación para la Educación, la Ciencia y la Cultura. 212 p.

Greslebin AG, Rajchenberg M (2003) Diversity of Corticiaceae sens. lat. in Patagonia, Southern Argentina. N. Z. J. Bot. 41(3): 437-446. doi: 10.1080/0028825X.2003.9512861

Hättenschwiler S, Fromin N, Barantal S (2011) Functional diversity of terrestrial microbial decomposers and their substrates. Comptes rendus biologies 334(5-6): 393-402. doi: 10.1016/j.crvi.2011.03.001

Hijmans RJ, Cameron SE, Parra JL, Jones PG, Jarvis A. (2005) Very high resolution interpolated climate surfaces for global land areas. International Journal of Climatology: A Journal of the Royal Meteorological Society 25(15): 1965-1978. doi: 10.1002/joc.1276

Horak E (1979) Fungi, Basidiomycetes, Agaricales and Gasteromycetes secotioides. Flora Criptogámica de Tierra del Fuego, Tomo XI, Fasc. 6. Fundación para la Educación, la Ciencia y la Cultura. 524 p. 
Horák J, Kout J, Vodka Š, Donato DC (2016) Dead wood dependent organisms in one of the oldest protected forests of Europe: investigating the contrasting effects of within-stand variation in a highly diversified environment. For. Ecol. Manage. 363: 229-236. doi: 10.1016/j.foreco.2015.12.041

Ibarra M, Caldentey J, Promis Á (2011) Descomposición de hojarasca en rodales de Nothofagus pumilio de la región de Magallanes. Bosque (Valdivia) 32(3): 227-233. doi: 10.4067/S0717-92002011000300004 Juutilainen K, Mönkkönen M, Kotiranta H, Halme P (2014) The effects of forest management on woodinhabiting fungi occupying dead wood of different diameter fractions. For. Ecol. Manage. 313: 283-291. doi: 10.1016/j.foreco.2013.11.019

Lee H, Jang Y, Choi YS, Kim MJ, Lee H, et al. (2014) Biotechnological procedures to select white rot fungi for the degradation of PAHs. J. Microbiol. Methods 97: 56-62. doi: 10.1016/j.mimet.2013.12.007

Legendre P, Legendre L (1998) Numerical Ecology. 2nd edn. Elsevier, Amsterdam.

Lencinas MV, Martínez Pastur G, Solán R, Gallo E, Cellini JM (2008) Forest management with variable retention impact over bryophyte communities of Nothofagus pumilio understory. Forstarchiv 79: 77-82. doi: 10.23760300-4112-79-77

Lencinas MV, Martínez Pastur G, Gallo E, Cellini JM (2009) Alternative silvicultural practices with variable retention improve bird conservation in managed South Patagonian forests. For. Ecol. Manage. 258, 472480. doi: 10.1016/j.foreco.2009.01.012

Lencinas MV, Martínez Pastur G, Gallo E, Cellini JM (2011) Alternative silvicultural practices with variable retention to improve understory plant diversity conservation in southern Patagonian forests. For. Ecol. Manage. 262, 1236-1250. doi: 10.1016/j.foreco.2011.06.021

Lencinas MV, Martínez Pastur G, Gallo E, Cellini JM (2014) Decreasing negative impacts of harvesting over insect diversity using variable retention silviculture in southern Patagonian forests. J. Ins. Conserv. 18: 479-495. doi: 10.1007/s10841-014-9661-5

Lencinas MV, Sola FJ, Martínez Pastur G (2017). Variable retention effects on vascular plants and beetles along a regional gradient in Nothofagus pumilio forests. For. Ecol. Manage. 406: 251-265. doi: 10.1016/j.foreco.2017.10.014

Lonsdale D, Pautasso M, Holdenrieder O (2008) Wood-decaying fungi in the forest: conservation needs and management options. Eur. J. For. Res. 127(1): 1-22. doi: 10.1007/s10342-007-0182-6

López Bernal P, Defossé GE, Quinteros PC, Bava JO (2012) Sustainable management of lenga (Nothofagus pumilio) forests through group selection system. Sustainable Forest Management-Current Research. Intech, Rijeka, p 45-66. 
Loreau M, Naeem S, Inchausti P, Bengtsson J, Grime JP, et al. (2001) Biodiversity and ecosystem functioning: current knowledge and future challenges. Science 294(5543): 804-808. doi:

10.1126/science. 1064088

Mansilla PR (2012) Evaluación de la alteración y restauración de los ciclos biogeoquímicos en bosques de Nothofagus pumilio de Tierra del Fuego afectados por prácticas de manejo forestal. Universidad de Buenos Aires, Buenos Aires, Argentina. 140 p.

Martínez Pastur G, Cellini JM, Peri PL, Vukasovic RF, Fernández MC (2000) Timber production of Nothofagus pumilio forests by a shelterwood system in Tierra del Fuego (Argentina). For. Ecol. Manage. 134(1-3): 153-162. doi: 10.1016/S0378-1127(99)00253-4

Martínez Pastur G, Peri PL, Fernández MC, Staffieri G, Lencinas MV (2002) Changes in understory species diversity during the Nothofagus pumilio forest management cycle. J. For. Res. 7(3): 165-174

Martínez Pastur G, Vukasovic RF, Lencinas MV, Cellini JM, Wäbo E (2003) El manejo silvícola de los bosques patagónicos: Utopía o Realidad. Actas XII Congreso Forestal Mundial. 7: 150-151

Moretto AS, Martínez Pastur G (2014) Litterfall and leaf decomposition in Nothofagus pumilio forests along an altitudinal gradient in Tierra del Fuego, Argentina. J. For. Sci. 60(12): 500-510. doi: 10.17221/74/2014-JFS

Nielsen UN, Ayres E, Wall DH, Bardgett RD (2011) Soil biodiversity and carbon cycling: a review and synthesis of studies examining diversity-function relationships. Eur. J. Soil Sci. 62(1): 105-116. doi: 10.1111/j.1365-2389.2010.01314.x

Paillet Y, Bergès L, Hjältén J, Ódor P, Avon C, et al. (2010) Biodiversity differences between managed and unmanaged forests: meta-analysis of species richness in Europe. Conservation Biology 24(1): 101-112. doi: 10.1111/j.1523-1739.2009.01399.x

Parisi F, Pioli S, Lombardi F, Fravolini G, Marchetti M, Tognetti R (2018) Linking deadwood traits with saproxylic invertebrates and fungi in European forests-a review. iForest-Biogeosciences and Forestry. 11(3): 423. doi: 10.3832/ifor2670-011

Pérez Flores M, Martínez Pastur G, Cellini JM, Lencinas MV (2019) Recovery of understory assemblage along 50 years after shelterwood cut harvesting in Nothofagus pumilio Southern Patagonian forests. For. Ecol. Manage. 450: 117494. doi: 10.1016/j.foreco.2019.117494

Persiani AM, Lombardi F, Lunghini D, Granito VM, Tognetti R, et al. (2016) Stand structure and deadwood amount influences saproxylic fungal biodiversity in Mediterranean mountain unmanaged forests. iForestBiogeosciences and Forestry 9(1): 115-124. doi: 10.3832/ifor1304-008

Peri PL, Lencinas MV, Bousson J, Lasagno R, Soler R, et al. (2016) Biodiversity and ecological long-term plots in Southern Patagonia to support sustainable land management: The case of PEBANPA network. 
Journal for nature conservation. 34: 51-64. doi: 10.1016/j.jnc.2016.09.003

Promis A, Caldentey J, Ibarra M (2010). Microclima en el interior de un bosque de Nothofagus pumilio y el efecto de una corta de regeneración. Bosque (Valdivia) 31(2): 129-139. doi: 10.4067/S071792002010000200006

Rajala T, Peltoniemi M, Pennanen T, Mäkipää R (2012) Fungal community dynamics in relation to substrate quality of decaying Norway spruce (Picea abies [L.] Karst.) logs in boreal forests. FEMS Microbiol. Ecol. 81(2): 494-505. doi: 10.1111/j.1574-6941.2012.01376.x

Rajchenberg M (2006) Los políporos (Basidiomycetes) de los bosques Andino Patagónicos de Argentina. Berlin, Germany, J Cramer Berlin \& Stuttgart.

Rayner AD, Boddy L (1988) Fungal decomposition of wood. Its biology and ecology. John Wiley \& Sons Ltd.

R Development Core Team (2016) R: A language and environment for statistical computing. R Version 3.2.3. R foundation for statistical computing, Vienna, Austria. Available at: http://www.R-project.org/.

Renvall P (1995) Community structure and dynamics of wood-rotting Basidiomycetes on decomposing conifer trunks in northern Finland. Karstenia 35: 1-51. doi: 10.29203/ka.1995.309

RStudio Team (2016) RStudio: integrated development for R. RStudio, Inc., Boston, MA. www.rstudio.com/

Sarkar D (2008) Lattice: multivariate data visualization with R.Springer, New York. ISBN 978-0-387-759685

Setälä H, McLean MA (2004) Decomposition rate of organic substrates in relation to the species diversity of soil saprophytic fungi. Oecologia 139(1): 98-107. doi: 10.1007/s00442-003-1478-y

Seibold S, Bässler C, Brandl R, Gossner MM, Thorn S, et al. (2015) Experimental studies of dead-wood biodiversity-a review identifying global gaps in knowledge. Biological Conservation, 191:139-149. doi: 10.1016/j.biocon.2015.06.006

Silva PV, Quinteros CP, Greslebin AG, Bava JO, Defossé GE (2016). Characterization of Nothofagus pumilio (lenga) understory in managed and unmanaged forests of central Patagonia, Argentina. Forest Science 63(2): 173-183. doi: 10.5849/forsci.15-156

Spagarino C, Martínez Pastur G, Peri P (2001) Changes in Nothofagus pumilio forest biodiversity during the forest management cycle. 1. Insects. Biodiversity \& Conservation. 10(12): 2077-2092. doi:

10.1023/A:1013150005926

Swift MJ (1977). The ecology of wood decomposition. Sci. Prog. 64: 175-199 
Toljander YK, Lindahl BD, Holmer L, Högberg NOS (2006) Environmental fluctuations facilitate species coexistence and increase decomposition in communities of wood decay fungi. Oecologia 148(4): 625-631. doi: $10.1007 /$ s00442-006-0406-3

van der Wal A, Geydan TD, Kuyper TW, De Boer W (2013) A thready affair: linking fungal diversity and community dynamics to terrestrial decomposition processes. FEMS Microbiol. Rev. 37(4): 477-494. doi: $10.1111 / 1574-6976.12001$

van der Wal A, Ottosson E, de Boer W (2015) Neglected role of fungal community composition in explaining variation in wood decay rates. Ecology 96(1): 124-133. doi: 10.1890/14-0242.1

van Soest PJ (1963) Use of detergents in the analysis of fibrous feeds. 2. A rapid method for the determination of fiber and lignin. J. Assoc. Off. Agric. Chem. 46: 829-835. doi: 10.1093/jaoac/46.5.829

Weedon JT, Cornwell WK, Cornelissen JHC, Zanne AE, Wirth C, Coomes DA (2009) Global meta-analysis of wood decomposition rates: a role for trait variation among tree species? Ecology Letters 12(1): 45-56. doi: 10.1111/j.1461-0248.2008.01259.x

Wickham H (2016) ggplot2: elegant graphics for data analysis. Springer, New York, US.

Zuur AF, leno EN, Walker NJ, Saveliev AA, Smith GM (2009) Mixed effects models and extensions in ecology with R. Springer, New York, US

\section{Figures}



MF - site 3
C - site 3
MF - site 2
C - site 2
MF - site 1
C - site 1
0,00
0,09
0,18
0,27
0,37

\section{Figure 1}

Hierarchical dendrogram of the cluster analysis showing dissimilarity between fungal assemblages of the 6 stands The dendrogram is based on Bray-Curtis dissimilarity index. A Bray-Curtis index 0 indicates identical species assemblage, while index $=1$ indicates totally different species assemblage. Ward distance linkage was used. MF and C indicate managed forest and control, respectively. Each stand is labeled with the treatment and site number. 

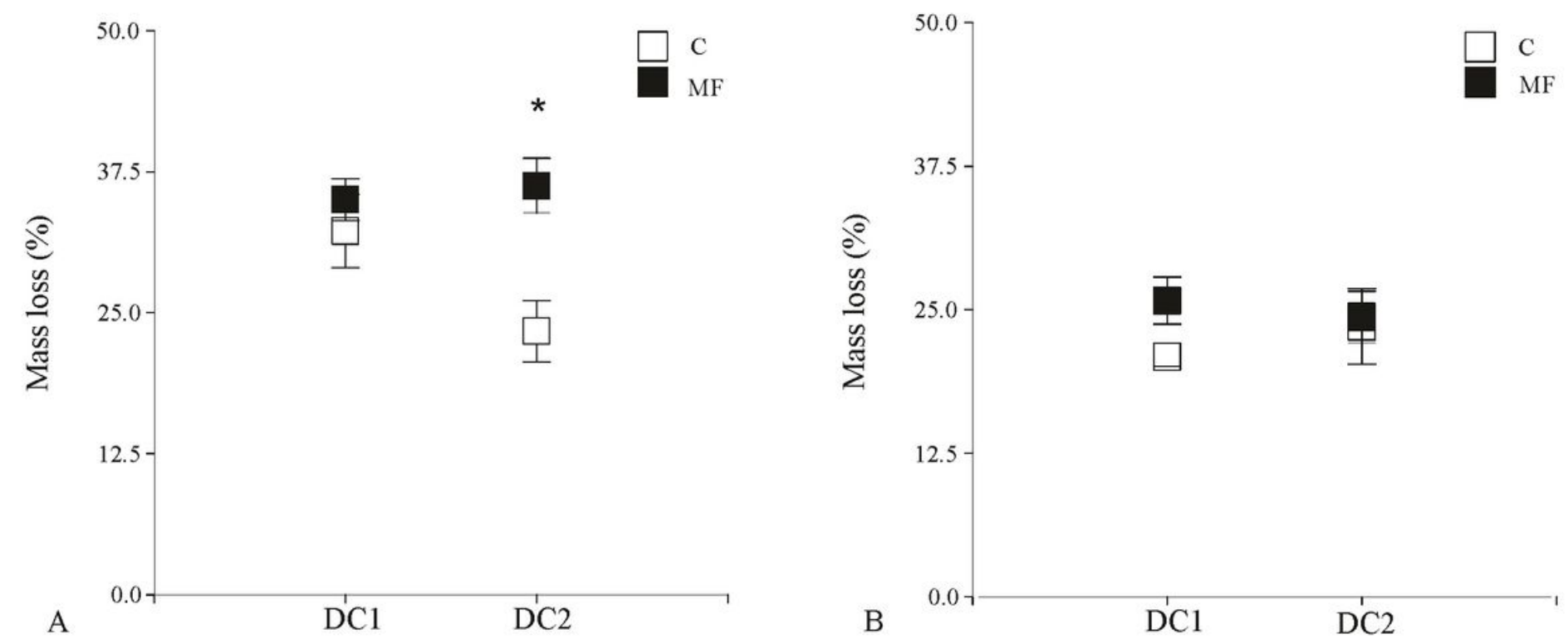

\section{Figure 2}

Mass loss of branches and twigs in different decay classes A: branches; B: twigs; DC1: incipient decay class DC2: intermediate decay class; MF: managed forests; C: control. Mass loss is presented as a percentage of initial mass. Mean values $( \pm$ Standard Error)

\section{Supplementary Files}

This is a list of supplementary files associated with this preprint. Click to download.

- OnlineResources.pdf 